\title{
Introduction: Amazonia, landscape and species evolution
}

\author{
Carina Hoorn $^{1}$ and Frank P. Wesselingh ${ }^{2}$ \\ ${ }^{1}$ University of Amsterdam, The Netherlands \\ ${ }^{2}$ Naturalis, Leiden, The Netherlands
}

\section{Motivation}

The Amazon drainage basin covers over 8 million $\mathrm{km}^{2}$ and has the largest rainforest on earth (Sioli 1984). The Amazon River is $6400 \mathrm{~km}$ long, from its source in the Andes to its mouth in the Atlantic, and the drainage basin includes a variety of landscapes such as the enigmatic tepuis in the north, the forested slopes at the foot of the Andes in the west, and the wide tracts of rainforest in the central part of the basin.

The region is renowned for its great biodiversity, both aquatic and terrestrial. Exact figures to quantify this diversity do not yet exist, and estimates of species numbers are still increasing. This incomplete understanding of species numbers makes any firm estimate impossible; nevertheless, the region is thought to harbour no less than 7500 butterfly species (possibly about $40 \%$ of the world butterfly species), 1500 species of birds (about onethird of the world total) and an estimated 11,200 tree species (Hubbell et al. 2008).

The Amazon system plays a significant role in the world's climate as it produces about $20 \%$ of the world's oxygen supply. Nutrients delivered by the Amazon River to the Atlantic Ocean help to foster oceanic life that sequesters globally relevant amounts of carbon (Subramaniam 2008), and in the terrestrial realm the Amazon rainforest is responsible for $10 \%$ of the net primary productivity of the whole terrestrial biosphere (http://earthobservatory.nasa. gov). Therefore, Amazonia is of the greatest concern to us all.

In spite of Amazonia's importance the number of studies on species composition and their distribution is still limited. Diversity hotspots seemingly coincide with biological field stations and specific large-scale biological expeditions (Nelson et al. 1990), and indicate just how much basic research still is required. Even the classification of habitats in Amazonia is far from straightforward (e.g. Kalliola et al. 1993) as major parts of the region are hardly accessible and remote sensing techniques cannot grasp the variety without substantial 'ground-truthing'.

If our knowledge of Amazonia's present is limited, this is even more so for its past. When did the Amazonian landscape and

Amazonia, Landscape and Species Evolution: A Look into the Past,

1 st edition. Edited by C. Hoorn and F.P. Wesselingh.

(C) 2010 Blackwell Publishing jungles arise? What climatic, chemical, geological and other non-biological processes were involved in the development of these ecosystems and sustain them now, and what part did they play in the previous episodic demise of these ecosystems? In order to assess ecosystem resilience it is imperative to understand the historical (i.e. geological) processes that have shaped Amazonian landscapes and their biota.

For decades scientists have speculated about the evolution of species and biodiversity. However, the scientific debate was mostly dominated by biologists and geomorphologists using species and geomorphology as a basis for their theories (Haffer 1969; Ab'Sabr 1982; Absy et al. 1991; Colinvaux et al. 2000, 2001; Haffer \& Prance 2001; see also Chapter 26) and few geologists were involved in this discussion. Scientists are now increasingly aware that the geological substrate in Amazonia, and the relatively young age of the Andes and the Amazon River, were of paramount importance in species evolution and distribution of diversity hotspots (e.g. Salo et al. 1986; Hooghiemstra \& Van der Hammen 1998; Lundberg et al. 1998; Lovejoy et al. 1998; Van der Hammen \& Hooghiemstra 2000; Nores 2002; Wesselingh and Salo 2006; Tuomisto 2007; Antonelli 2008) yet an undisputed theory about the timing and context of Amazonian diversifications - in the light of geological evidence- still has to materialize.

Geology only recently started playing a role in the debate on the origin of biodiversity as it was hampered by the same obstacles as the biological and geomorphological sciences - the lack of firm evidence due to the difficult access to the terrain. However, in the past two decades geological studies in Amazonia quickly followed one another. The sedimentary environments in Amazonia and their age (e.g. Räsänen et al. 1987; Hoorn 1993; Wesselingh et al. 2002; Hovikoski 2006), the ancient nature of rainforests (e.g. Morley 2000; Jaramillo et al. 2006), the importance of soil heterogeneity and distribution in relation to floristic biodiversity (e.g. Kalliola \& Flores-Paitan 1998; Ruokolainen et al. 2007), past climate dynamics (Sugden 2000; Bush \& Flenley 2006; Bush et al. 2007) and the exact age of the establishment of the Amazon River (Dobson et al. 2001; Figuereido et al. 2009) are but a few of the thrilling insights that were obtained.

Simultaneously, a relatively young branch of science, DNA studies, increasingly suggested that the origin of extant biodiversity dates back well before the Quaternary (Antonelli 2008; 
Rull 2008) and may have coincided with regional geological events (see Chapters 23-25). Consequently, at the turn of the millennium, geology and biology were drawn to each other in a concerted effort to explain the origin of Amazonian biodiversity and landscapes.

\section{A journey through the geological history of Amazonia}

The scientific advances of the past two decades, and the newly gained perception that biotic and abiotic evolution might be intimately related, demanded an interdisciplinary, multinational effort to summarize the state of the art in Amazonian geological sciences. This book attempts to fulfil this role. It not only presents an outline of the geological history, but also assesses the implications of the geological past for landscape evolution and biotic diversity. The contributors show that the development of Amazonian diversity is intimately linked to landscape evolution, and that modern Amazonian ecosystems were formed during the geodynamic processes of the Cenozoic. The implication of this work is that before the Quaternary there were periods with even more diverse ecosystems.

The contributions to this book are grouped into five themes, corresponding to the book's five parts. The first of these themes discusses the origin, architecture and stratigraphic and tectonic relationships of the major geological units of the eastern Andes and Amazonia. The second theme focuses on the Amazonian sedimentary record from the Mesozoic era to the Quaternary period. This record is subdivided into cratonic and Andean-driven depositional systems although Neogene and Quaternary systems are a combination of both Andean and cratonic fluvial systems. In addition, megafan depositional systems in western Amazonia are also reviewed. Climatic evolution and the implications for the Amazonian region during the Miocene are assessed in the third part. The Amazonian palaeontological record of the aquatic and terrestrial realms constitutes the fourth part of the book. Despite the uneven concentration of fossiliferous deposits in western Amazonia and the adjacent Andes, the palaeontological chapters provide an in-depth insight into the development of Amazonian floras and faunas. The final, fifth, part of the book is concerned with modern perspectives on the origin of Amazonian biodiversity. The book concludes with a chapter by Wesselingh et al., who summarize the highlights of each chapter and provide a synopsis of the Cenozoic history of Amazonia. The best localities for observing the outcrops and fossils are shown in Fig. 1.1.

\section{Main geological processes shaping Amazonia through time}

The geography of Amazonia was shaped during three principal geological phases. The first was a Proterozoic phase (3-1 Ga [gigayears]) of cratonic formation dominated by magmatism, continental accretion and tectonic processes (see Chapter 2 by Kroonenberg \& de Roever). The craton forms most of eastern Amazonia and consists of ultrastable basement with landscapes that date back to the Cretaceous and Paleogene. In terms of biodiversity these areas are relatively poor compared to the nutrientrich, Andean-dominated western part of Amazonia (see Chapters $21 \& 22)$. At the end of the Proterozoic a series of east-west orientated intracratonic sedimentary basins were formed, which acted as fluvial conduits. Throughout geological history basement reactivation formed 'arches' that, at different times, created drainage divides. Seismic data and new stratigraphic charts from the Brazilian oil company Petrobras illustrate the development of these sedimentary basins in Brazilian Amazonia (see Chapter 3 by Wanderley Filho et al.).

The second major geological phase was characterized by rifting and break-up of the supercontinent Pangaea. This period also saw the opening of the Atlantic (Jurassic, c. $195 \mathrm{Ma}$ ) during which the Americas became fully separated from Europe and Africa. The separation was completed during the Cretaceous after which sedimentation of the intracratonic basins was resumed (c. $120 \mathrm{Ma}$ ). The third and final geological phase was determined by changes in plate configuration along the Pacific. This plate activity was an aftermath of the continental break-up and ultimately responsible for the uplift of the Andean Cordilleras that was initiated during the Cretaceous.

Pulses of uplift continued throughout the Cenozoic; however, Andean tectonism only reached a climax during the Late Miocene and Pliocene (c. 10-4 Ma). This resulted in intense denudation, increased subsidence in the sub-Andean zone and progression of the sedimentary wedge into Amazonia, and ultimately connected the inland drainage system with the Atlantic Ocean creating the Amazon River (see Chapters $4 \& 5$ by Mora et al. and Roddaz et al.; Figuereido et al. 2009).

Andean uplift remained high during the Pliocene while subduction of the Nazca Ridge caused tectonic uplift of the Fitzcarrald Arch (southeastern Peru and adjacent Brazil). As a consequence the western Amazonian lowlands, which during the Miocene formed continuous aquatic habitats, became fragmented and dissected (see Chapter 6 by Espurt et al.). A final marker event in the geological history of northern South America was the closure of the Panama isthmus around $3 \mathrm{Ma}$. Although tectonism is ongoing, this concluded the Present geographical configuration of the South American continent, its landscape and modern drainage systems (see also Chapter 26).

\section{Cratonic and Andean-driven depositional systems}

River systems of cratonic descent or local lowland origin have dominated Amazonian landscapes throughout their history. In this book we review the Mesozoic and Cenozoic cratonic fluvial systems by comparing four different fluvial formations that range in age from Cretaceous to Late Neogene (see Chapter 7). From the Oligocene onwards Andean-driven depositional systems dominated the sub-Andean zone and western Amazonia. These systems extended to at least 1.5 million $\mathrm{km}^{2}$ during the Miocene and were characterized by very large lakes and wetlands and occasional marine influence. During the Early and Middle Miocene a lakeand wetland-dominated system occurs (Pebas phase) whereas in the Late Miocene the newly formed Amazon River introduces a fluvial element into this otherwise wetland-dominated system (Acre phase) (see Chapter 8). Andean drainages are crucial for the soil development and distribution of species-diverse vegetation on nutrient-rich Andean-derived substrate. Instead relatively species-poor vegetation develops on the craton-derived substrate.

The presence and extent of marine influence in the history of Amazonia has been a hotly debated topic. In Chapter 9, Hovikoski 


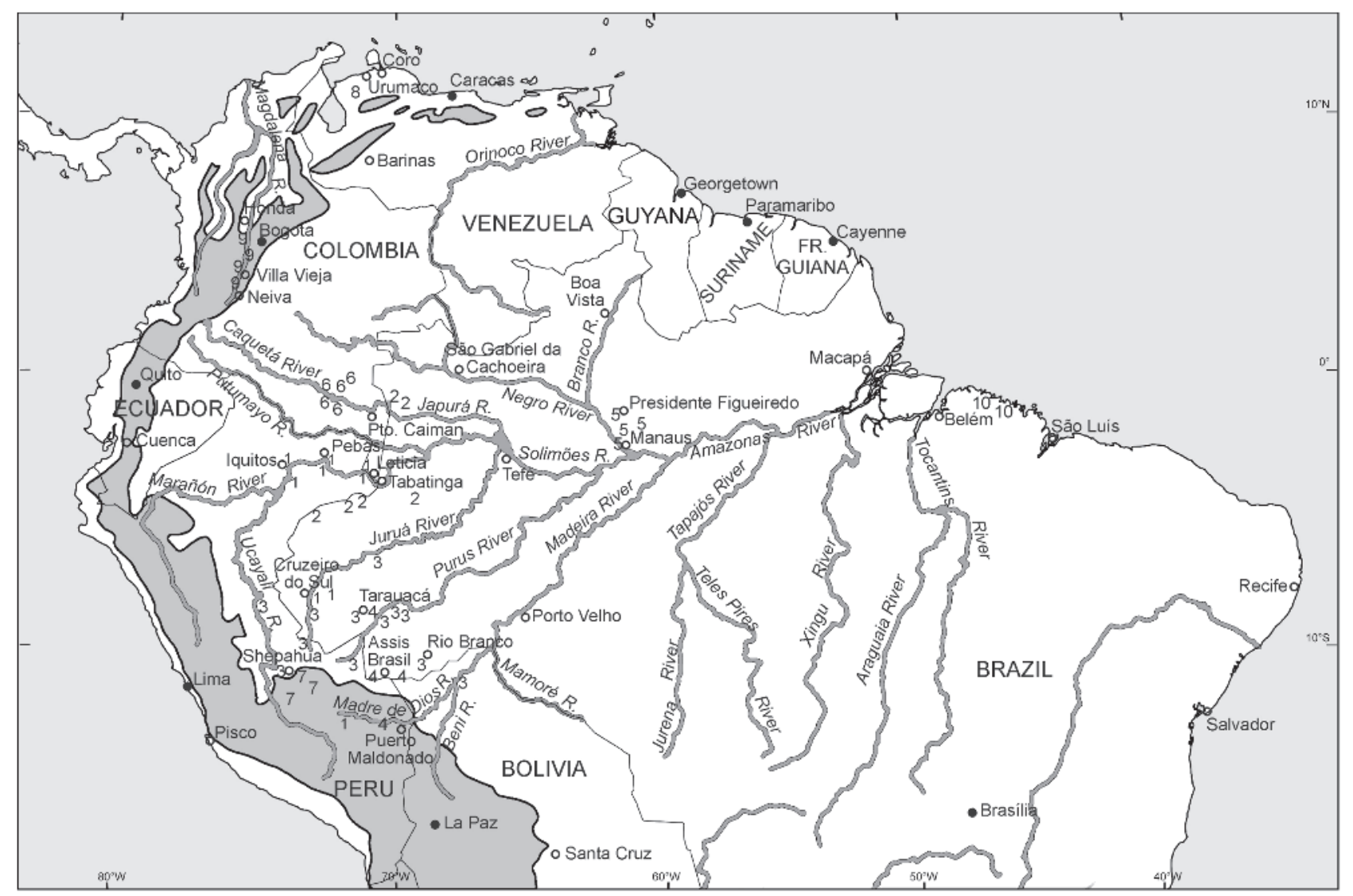

Fig. 1.1 This map represents the principal Amazonian rivers and outcrops of Cretaceous and Cenozoic origin in Amazonia that are referred to in the various chapters of this book. The locations are represented as numbers and either indicate the author or the common name of the locality. (1) Pebas/Solimões outcrops (Hovikoski et al., see Chapter 9). (2) Pebas/Solimões outcrops (Hoorn et al., see Chapter 8). (3) Fossil mammals (Negri et al., see Chapter 15). (4) Localities of both Negri et al. and Hovikoski et al. (the localities close to the city of Assis Brasil are situated on the margins of the Acre River, which is not represented here. (5) Cretaceous-Paleogene Alter do Chão (source Petrobras, in Hoorn et al., see Chapter 7). (6) Neogene fluvial deposits of cratonic origin (Hoorn et al., see Chapter 7). (7) Fitzcarrald mammal fauna (Negri et al., see Chapter 15). (8) Lower Miocene Castillo Formation - other important Venezuelan localities are placed close to/into the cities of Urumaco (Upper Miocene Urumaco Formation) or Barinas (Middle Miocene Parángula Formation) - see Riff et al., Chapter 16. (9) Middle Miocene Honda Group (La Venta Fauna), Magdalena Valley. (10) Atalaia Beach (Salinópolis city) and Ilha de Fortaleza (Sao João de Pirabas city), Lower Miocene Pirabas Formation (see Riff et al., Chapter 16). Map made by D. Riff and J. van Arkel.

et al. argue that in the past $30 \mathrm{Ma}$ well-documented episodes of marine influence in Amazonia are limited to the Miocene. However, there is no evidence for fully established marine corridors ('seaways') throughout the South American continent in the Cenozoic.

The Cenozoic Andean uplift and increased denudation rates further resulted in megafan systems along the Andean foothills (see Chapter 10 by Wilkinson et al.). Megafans are low-gradient river systems choked by sediments, which force them to continuously change their courses. Understanding their dynamic behaviour sheds light on the development and distribution of aquatic biota. The extent of megafan depositional systems in the history of Amazonia is greatly underestimated.

Late Neogene and Quaternary fluvial systems are further explored in Chapter 11, by Irion \& Kalliola. They outline the fluvial depositional environments and processes from the foreland basins in the west to the mouth of the Amazon in the east, and consider the resulting landforms, which dominate a major part of the surface of lowland Amazonia. Quaternary fluvial systems along the trunk Amazon River have been dominated by strong eustatic-driven base-level changes.

\section{Amazonian climate}

Although palaeoclimatic data are hard to obtain, isotope data from fossil molluscs and cyclicity in the sediment beds indicate that the modern Amazonian hydrological cycle, which ensures the yearround wet conditions that sustain the rainforests, was in place in the Miocene (see Chapter 12). Experimental climate modelling for a low-elevation Andes and the effect on Amazonian climate is explored by Sepulchre et al. in Chapter 13. Based on their model, the role of the Andes in maintaining permanent wet conditions in the lowlands is seemingly less prominent than one would expect. 
The wet character of the Amazonian climate is mostly the result of the Amazonian hydrological cycle. However, a lower Andes would create different precipitation patterns than at Present, and the removal of the Andes would increase seasonality.

Another climatic controlling mechanism that affects Amazonia is the El Niño Southern Oscillation (ENSO). In Chapter 14 Bookhagen \& Strecker explore the influence of the negative ENSO climatic phenomenon (also known as La Niña) on sediment influx and aggradation in the fluvial systems. The extreme high water levels as a result of high precipitation during the negative ENSO years have a disproportionate effect on denudation and are thus extremely important to the Amazonian river dynamics.

\section{The palaeontological record in Amazonia}

Amazonia has hosted a highly diverse mammal fauna at least since the Paleogene. Recently discovered Eocene-Oligocene faunas and Middle Miocene faunas from the Peruvian-Brazilian border area provide us with detailed information on the faunal composition. However, most noticeable is the rich Late Miocene fauna from Acre (Brazil), which includes species with remarkably large forms (see Chapter 15 by Negri et al.). The demise of the giants coincided with the arrival of North American immigrants associated with the emergence of the Panama land bridge (Stehli \& Webb 1995).

The Amazonian crocodile and turtle faunas indicate that during the Cenozoic diversification was slow, but culminated in the Miocene fauna with a diversity and disparity that remains unrivalled (see Chapter 16 by Riff et al.). This fauna contains the largest crocodile and turtle that ever lived, as well as a remarkable diversity of gharial species. The Pliocene and Quaternary faunas are clearly less diverse, a feature linked by the authors to global cooling and the disappearance of the large productive aquatic ecosystems of the Miocene.

The diverse Amazonian fish fauna, too, has a long history of gradual diversification, as is shown by Lundberg et al. in Chapter 17 . Already in the Miocene an essentially modern fauna inhabited the Amazonian aquatic ecosystems. The fishes have provided some of the best indications of the changing outline of Amazonian watersheds throughout their Cenozoic history. Especially well reflected in this fauna is the separation, during the Late Neogene, of northern coastal and Andean drainages from Amazonia.

The Miocene invertebrate fauna developed through a large evolutionary radiation of endemic mollusc and ostracod species in the long-lived lakes of the Pebas megawetland (see Chapter 18 by Wesselingh \& Ramos). In addition, species associations characteristic for restricted marine conditions occur in some intervals. Nevertheless, since the Late Miocene the Amazonian rivers and lakes have been the domain of a low-diversity fluvial mollusc fauna and a stunningly diverse decapod fauna.

The palynological and palaeobotanical record of plants shows us that modern angiosperm-dominated rainforests existed in Amazonia throughout the Cenozoic (see Chapter 19 by Jaramillo et al.). Diversity culminated during the Eocene, and a major extinction occurred at the Eocene-Oligocene transition. Modern genera were already present during the Miocene, when the current rainforest biome developed and diversities were as high, or even higher, than at Present. In Chapter 20 Behling et al. further show that although the Quaternary glaciations affected the distribution of plant species in Amazonia, they did not seem to promote speciation in the Amazonian lowlands. During the Quaternary the fringes of the rainforest were affected at precessional timescales, but the core of lowland Amazonia remained covered by forest. Nevertheless, the composition of forests changed through different parts of the glacial cycle.

\section{Modern perspectives on the origin of Amazonian biota}

In Chapter 21 ter Steege et al. present the region-wide diversity patterns and explore their relationships with a range of factors, such as edaphic variation and climate. Although the documentation of biodiversity is notoriously incomplete, the addition of niche modelling has substantially improved our insights, and will do so in future. The importance of edaphic heterogeneity for plant diversity is further illustrated by Duivenvoorden \& Duque in Chapter 22, which investigates the relationships between the abiotic environment (geology, geomorphology, soils) and biodiversity.

Recently, many important new insights into the origin of Amazonian biodiversity and biogeography have emerged from molecular studies. In Chapter 23 Pennington \& Dick review evidence from plants, while Antonelli et al. in Chapter 24 review the development of tetrapods, and the fish are treated in Chapter 25 by Lovejoy et al. All contributors caution about hasty interpretation of age estimates from so-called molecular clock studies because of the underlying assumptions. Nevertheless, results clearly indicate that the origination of modern biota has been a steady process that mostly played in the Cenozoic.

\section{Outlook}

New insights and data about the origin of Amazonian landscapes, ecosystems and biodiversity are accumulating even as we compile this book. Further integration of the various biological, geographical and geological disciplines, as well as further technical and conceptual developments within the different fields, will continue to bring new insights about the Amazonian biological system and its resilience, as well as the importance of Amazonia on global processes on a variety of time scales.

As Amazonia is suffering badly from human activities, new and much more ambitious efforts to assess its biodiversity, mostly by time-consuming field-based taxonomic inventories combined with niche modelling, are paramount to get a better sense of the magnitude of species richness and to identify further priorities for conservation. Molecular studies have become an indispensable tool in identifying real species richness.

Further processing of subsurface data, both seismic as well as borehole data and samples, will add to our knowledge of the development of the region and its landscapes. Study of the reaction of biodiversity to previous natural perturbations will bring more insights about ecosystem resilience, at a time when such insights are so badly needed.

Raising awareness of the unique and amazing diversity of life in Amazonia is needed in order to achieve better protection 
for the region and its biota. With this book we hope to enhance appreciation of the vast timescales that were needed to create these great ecosystems, which we are challenging so profoundly at this moment in history.

\section{Acknowledgements}

This book is the result of an intense cooperative effort of more than a hundred people from different continents who all share a scientific, and often a personal, interest in Amazonia. As editors we were overwhelmed by the enthusiasm of all our colleagues who participated in this project. The novel and original insights presented through the chapter authors and reviewers encouraged us at all times. It has been a long journey during which many things happened in our personal lives; however, the book project always joined us together. The compilation of this book has been a long process ( 2.5 years to reach publishable form) but during that process we have learnt a great deal about Amazonian history from colleagues old and new. However, this book would not have reached its present shape without the help of all the reviewers (sometimes in a dual role of authors) who shared their time with us and helped us improve the manuscripts.

A big thanks to the following people (in alphabetical order): Frank Audemard, German Bayona, Bodo Bookhagen, Chris Brochu, Alberto Cione, Joost Duivenvoorden, Richard Field, Jorge Figueiredo, Paul Fine, Jose I. Guzman, Mathias Harzhauser, Ren Hirayama, Henry Hooghiemstra, Jussi Hovikoski, Teresa Jordan, Wolfgang Junk, Risto Kalliola, Salle Kroonenberg, John Lundberg, Bruce MacFadden, Richard Madden, Koen Martens, Jose Ignacio Martinez, Mark Maslin, Francis Mayle, Michael McClain, Bob Morley, Brice Noonan, Onno Oncken, Jim Patton, Toby Pennington, Sir Ghillean Prance, George Postma, Victor Ramos, Roberto Reiss, Colombo Tassinari, Eric Tohver, Graham Wallis, Wilfried Winkler, Martin Zuschin, and a number of colleagues who requested to remain anonymous.

Our editorial advisors, Hubert Vonhof, Salomon Kroonenberg and Henry Hooghiemstra, helped us with many tasks related to the book. But above all we owe them special thanks for standing beside us and giving us all their support and advice during crucial moments in this project. Overseas, at the Petrobras offices, we warmly thank Paulus van der Ven for his continual support; Petrobras management are also thanked for the valuable subsurface information that the company made available to this book.

None of this would have ever happened, though, if Ian Francis from Wiley-Blackwell Publishers had not believed in this project in the first place. We thank him for his trust and also thank Delia Sandford and Kelvin Matthews, also from the publishing house, and project manager, Nik Prowse, for their patience, help and advice in this project.

The success of this project is also based on the unconditional support of our beloved ones (Alastair Milne and Maaike Wickardt, respectively) who enabled us to complete the process of the making of this book. Our families have born most of the brunt of our work. We are so happy they still love us and are in good health with us to enjoy this milestone after considerable periods of mental absence.
Finally, we are immensely thankful that Thomas van der Hammen managed to complete the prologue of this book, this in spite of his deteriorating health. Thomas has been our mentor, who inspired us to take on the mighty Amazon. We dedicate this volume to him in admiration of his longstanding commitment to Amazonian research, and hope that this book will inspire young scientists to undertake further research, just as Thomas inspired us to engage in research in wonderful Amazonia. There is still so much to research out there in the virgin rainforest of South America...

\section{References}

Ab'Sabr, A.N. (1982) The paleoclimate and palaeoecology of Brasilian Amazonia. In: Prance, C.T. (ed.) Biological Diversification in the Tropics. New York: Columbia University Press, pp. 41-59.

Absy, M.L., Cleef, A.L., Fournier, M., Martin, L., Servant, M., Sifeddine, A., Da Silva, M.F., Soubies, F. Suguio, K., Turcq, B., Van der Hammen, T. (1991) Mise en évidence de quatre phases d'ouverture de la forêt dense dans le sud-est de l'Amazonie au cours des 60.000 dernières années. Première comparaison avec d'autres régions tropicales. C.R. Acad. Sci. Paris 312, 673-678.

Antonelli, A. (2008) Spatiotemporal evolution of Neotropical organisms: new insights into an old riddle. Doctoral thesis. University of Gothenburg, Göteborg, Sweden, 84 pp.

Bush, M.B., Crisci, J., Whittaker, R.J. (2007) Special issue: Conservation and Biogeography of Amazonia. J Biogeog 34, 1289.

Bush, M., Flenley, J. (2006) Tropical Rainforest Responses to Climatic Change. Springer.

Colinvaux, P.A., De Oliveira, Bush, M. (2000) Amazonian and Neotropical plant communities on glacial time-scales: The failure of the aridity and refuge hypothesis. Quaternary Sci Rev 19, 141-170.

Colinvaux, P.A., Irion, G., Rasanen, M.A., Bush, M., de Mello, J. (2001) A paradigm to be discarded: Geological and paleoecological data falsify the Haffer \& Prance Refuge Hypothesis of Amazonian sopeciation. Amazoniana 16, 609-646.

Dobson, D.M., Dickens, G.R., Rea, D.K. (2001) Terrigenous sediment on Ceara Rise: a Cenozoic record of South American orogeny and erosion. Palaeogeogr Palaeocli 165, 215-229.

Figuereido, J., Hoorn, C., van der Ven, P., Soares, E. (2009) Late Miocene onset of the Amazon River and the Amazon deep-sea fan: Evidence from the Foz do Amazonas Basin. Geology 37, 619-622.

Haffer, J. (1969) Speciation in Amazonian forest birds. Science 165, 131-137.

Haffer, J., Prance, G.T. (2001) Climatic forcing of evolution in Amazonia during the Cenozoic: On the refuge theory of biotic differentiation. Amazoniana 16, 579-608.

Hooghiemstra, H., Van der Hammen, T. (1998) Neogene and Quaternary development of the neotropical rain forest: the forest refugia hypothesis, and a literature overview. Earth-Sci Rev 44, 147-183.

Hoorn, C. (1993) Marine incursions and the influence of Andean tectonics on the Miocene depositional history of northwestern Amazonia: results of a palynostratigraphic study. Palaeogeogr Palaeocl 109, 1-55.

Hovikoski, J. (2006) Miocene Western Amazonia in the light of sedimentological and ichnological data. $\mathrm{PhD}$ thesis, Annales Universitatis Turkuensis, AII, 1-138.

Hubbell, S.P., He, F., Condit, R., Borda-de-Água, L., Kellner, J., ter Steege, H. (2008) How many tree species are there in the 
Amazon and how many of them will go extinct? PNAS 105, 11498-11504.

Jaramillo, C., Rueda, M.J., Mora, G. (2006) Cenozoic plant diversity in the Neotropics. Science 311, 1893-1896.

Kalliola, R., Flores-Paitan, S. (eds) (1998) Geoecologia y desarrollo Amazonico: estudio integrado en la zona de Iquitos, Peru. Annales Universitatis Turkuensis, A II, 114, 544 pp.

Kalliola, R., Puhakka, M., Danjoy, M.W. (eds) (1993) Amazonia Peruana, Vegetación Humeda Tropical en el Llano Subandino. Turku: University of Turku.

Lovejoy, N.R., Bermingham, R.E., Martin, P. (1998) Marine incursions into South America. Nature 396, 421-422.

Lundberg, J.G., Marshall, L.G., Guerrero, J., Horton, B., Malabarba, M.C.S.L., Wesselingh, F. (1998) The stage for Neotropical fish diversification: A history of tropical South American rivers. In: Reis, R.E., Vari, R.P., Lucena, Z.M., Lucena, C.A.S. (eds) Phylogeny and Classification of Neotropical Fishes. Porto Alegre: Edipucrs, pp. 13-48.

Morley, R.J. (2000) Origins and Evolution of Tropical Rainforests. New York: John Wiley \& Sons.

Nelson, B.W., Ferreira, C.A.C., da Silva, M.F., Kawasaki, M.L. (1990) Endemism centres, refugia and botanical collection density in Brazilian Amazonia. Nature 345, 714-716.

Nores, M. (2002) An alternative hypothesis for the origin of Amazonian bird diversity. J Biogeogr 26, 475-485.

Räsänen, M.E., Salo, J.S., Kalliola, R.J. (1987) Fluvial perturbance in the western Amazon Basin: Regulation by long-term Sub-Andean tectonics. Science 238, 1398-1401.

Rull, V. (2008) Speciation, timing and neotropical biodiversity: The Tertiary-Quaternary debate in the light of molecular phylogenetic evidence. Mol Ecol 17, 2722--2729.
Ruokolainen, K., Tuomisto, H., Macía, M.J., Higgins, M.A., Yli-Halla, M. (2007) Are floristic and edaphic patterns in Amazonian rain forests congruent for trees, pteridophytes and Melastomataceae? J Trop Ecol 23, 13-25.

Salo, J., Kalliola, R., Häkkinen, I., Mäkinen, Y., Niemelä P. et al. (1986) River dynamics and the diversity of Amazon lowland forest. Nature $322,254-258$.

Sioli, H. (ed.) (1984) The Amazon: Limnology and Landscape Ecology of a Mighty Tropical River and its Basin. Dordrecht, Boston, Hingham, MA: W. Junk.

Stehli, F.G., Webb, S.D. (1985) The Great American Biotic Interchange. Topics in Biogeology, vol. 4. New York, London: Plenum Press, $532 \mathrm{pp}$.

Subramaniam, A. (2008) Amazon River enhances diazotrophy and carbon sequestration in the tropical North Atlantic Ocean. PNAS 105, 10460-10465.

Sugden, D. (ed.) (2000) Quaternary climate change and South America. J Quaternary Sci (Special Issue) 15, 299-468.

Tuomisto, H. (2007) Interpreting the biogeography of South America. J Biogeogr 34, 1294-1295.

Van der Hammen, T., Hooghiemstra, H. (2000) Neogene and Quaternary history of vegetation, climate, and plant diversity in Amazonia. Quaternary Sci Rev 19, 725-742.

Wesselingh, F.P., Salo, J. (2006) A Miocene perspective on the evolution of Amazonian biota. Scripta Geologica 133, 439-445.

Wesselingh, F.P., Räsänen, M.E., Irion, G.E., Vonhof, H.B., Kaandorp, R., Renema, W., Romero Pittman, L., Gingras, M. (2002) Lake Pebas: a palaeoecological reconstruction of a Miocene, longlived lake complex in western Amazonia. Cainozoic Res 1, 35-81. 